\title{
The effect of biology teaching with concept cartoons based on constructivist learning approach on student achievement and permanence of knowledge
}

\author{
Ali Aslan*1,2 (iD), Tubanur Aslan Engin ${ }^{3}$ (D), Gulbubu Kurmanbekova ${ }^{1}$ iD, Fethi Kayalar ${ }^{4}$ iD, \\ Filiz Kayalar $^{5}$ iD, Yalcin Karagoz ${ }^{6}$ iD, Adem Engin ${ }^{3}$ iD \\ ${ }^{1}$ Kyrgyz-Turkish Manas University, Faculty of Science, Department of Biology, 720038, Bishkek, Kyrgyzstan \\ ${ }^{2}$ Yuzuncu Yil University, Faculty of Pharmacy, Department of Pharmacology, 65080, Van, Turkey \\ ${ }^{3}$ Hakkari University, Vocational School of Health Services, Program of Medical Laboratory Techniques, 30000, Hakkari, Turkey \\ ${ }^{4}$ Erzincan Binali Yildirim University, Faculty of Education, Department of Educational Sciences, 24100, Erzincan, Turkey \\ ${ }^{5}$ Erzincan Binali Yildirim University, Faculty of Art and Science, Department of Science of Translation, 24100, Erzincan, Turkey \\ ${ }^{6}$ Agri Ibrahim Cecen University, Faculty of Pharmacy, Department of Pharmaceutic Botany, 04100, Agri, Turkey
}

\begin{abstract}
The aim of this study is to investigate the effect of concept cartoons and biology teaching based on a constructivist learning approach on student achievement and permanence of knowledge. The study group consists of 49 students studying in two of the 10th digital classes of Kazım Karabekir Technical and Industrial Vocational High School in the Yunus Emre district of Erzurum. At the stage of data collection, biology achievement tests including three-stage pre-test, post-test and permanence test consisting of 25 questions related to the subject of "Ecosystem Ecology", which is the third unit of the biology course, were prepared and used from the preparation books of the Student Selection Examination (ÖSS). In the study in which the pretest, posttest control group quasi-experimental design was used, the subjects were applied to the control group with the traditional straight expression method, and the teaching method was applied to the experimental group with the researched concept cartoons. The cartoons were given to the experimental group as a material, and the lesson was presented as slides, supported by cartoons, and actively processed in the form of questions and answers. As a result of the evaluation of the data, there was a statistically significant difference in favor of the experimental group $(p<0.05)$ according to the posttest scores obtained from the achievement test in the experimental group, where the teaching was performed with concept cartoons, and there was a significant difference between the groups in terms of retention test scores made after 4 weeks $(p<0.05)$ was observed. At the end of the study, it was understood that teaching with concept cartoons had a positive effect on providing students to learn biology knowledge compared to the traditional method.
\end{abstract}

Keywords: Biology; cartoon; concept cartoons; constructivist teaching method; permanent learning

\section{Introduction}

Rapid developments in science and modern technology based on them have been the basis for the development of biology, and have led to an increase and change in knowledge (Buckley and Michel, 2020; Ozyigit, 2020).
These developments made it necessary to make changes in the aims of the education system. With the efforts to prepare science programs in our country since the 1970s in accordance with the developments of the age, and transferring knowledge based on rote learning, education has changed to give students the scientific thinking and behavioral abilities, and methods of

\footnotetext{
* Corresponding author.

E-mail address: aliaslan@yyu.edu.tr, ali.aslan@manas.edu.kg (A. Aslan). https://doi.org/10.51753/flsrt.824378 Author contributions

Received 11 November 2020; Accepted 1 February 2021

Available online 9 February 2021

(C) 2021 Dergipark. All rights reserved.
} 
obtaining and using knowledge that they will use throughout their lives (Yesilyurt, 2005). One of the important goals recent education system is to get away from rote-based education and to create permanent knowledge that increases productivity. (Kete et al., 2009; Uslu and Celikoz, 2020).

The emphasis on how to make learning more effective and permanent is the basis of Educational Science. Learning is a process that takes place by organizing the information in short and long-term memory with various methods and applications and making it permanent as a result of interactions with the external environment (Wiewiora et al., 2020). In this process, one of the learning approaches that enable students to actively participate and practice by doing, instead of transferring the information to students' minds sequentially, is the constructivist approach (Inel et al., 2009). This approach to learning means that knowledge cannot be constructed passively or without a personal contribution, that understanding is the result of adaptation, that the person understands the subject by harmonizing with his own experiences, knowledge, and that the knowledge is created as a result of interaction, the language used and the social structure. That plays an important role in interaction (Kwahk and Park, 2018; Langley et al., 2018; Neeley and Leonardi, 2018).

Constructivist approach is the view that is formed by the combination of theories such as productive learning and discovery learning by reconstructing the knowledge by attributing its own meaning as a result of one's experiences and observations. According to this approach, the realization of meaning in interaction with the environment, the stimulus of cognitive contradiction and the search for the nature of what is to be learned are important conditions for learning to occur (Silva and Francis, 2020). Many of the learning psychologists who support the necessity of these conditions agree that learning occurs as a result of the individual's interaction with his environment and creates a change in the individual's behavior. The interaction between the individual and his environment is possible with the effect of the stimulus received by the individual and the individual's reaction to the stimulus (da Costa and Pelissari, 2016; Klein et al., 2019). Therefore, all activities and materials in the learning environment will affect learning (Demiralp, 2007).

The realization of more adequate and high level learning in teaching can be achieved by providing information in different ways (such as audio-visual) in the teaching environment and creating multimedia in teaching (Gunawardhana and Palaniappan, 2016). The teaching environment should be supported with materials in order to achieve this and to make the teaching more concrete and simplify the subject. Materials used in teaching are one of the basic elements of quality education (Naude and Meier, 2019). Materials selected in accordance with the subject and purpose bring the taught subject alive, enrich the teaching process and increase learning. Materials also broaden students' interests and increase their motivation (Demiralp, 2007; Fryer et al., 2017).

The use of the materials can increase the students' interest in the course and enable them to make inquiries about the subject by ensuring their participation in the lesson. As the presentation of audio-visual tools in the form of materials suitable for the lesson will appeal more to the sensory organs, so will the learning be permanent. Thus, learning will take place according to the constructivist approach rather than rote learning and forgetting will be too late (Opare et al., 2018; Afrizon et al., 2019).
In biology teaching, biology concepts, many of which are abstract and difficult to learn, should be learned in an effective, meaningful and permanent way, and new methods should be used by moving away from classical methods in order to prevent mislearning (Cakmak and Havedanli, 2004). Students' learning about the concepts and their ability to establish a relationship between the concepts depend on the preferred teaching method and the use of appropriate material selected for that method (Ozalp, 2006).

According to the constructivist approach, since students need to be active in the process of structuring information, it is important to use visual tools that can add students to the lesson, create discussion environments, and enable them to learn more meaningfully (Balim et al., 2008; Marques et al., 2018). It is thought that students perceive abstract and incomprehensible concepts such as biology concepts better with the help of visual tools (diagram, graphic, photograph, picture). In addition, it is known that visual memory is more easily remembered than verbal memory, and all kinds of visual communication tools such as drawing, diagrams and pictures help students to establish a neural information network and improve visual memory (Ozalp, 2006; Tyler-Wood et al., 2018).

According to recent researches, it is stated that cartoons can be used as visual education material in student-centered education with a constructivist learning approach (Hourani et al., 2017; Liang et al., 2019).

Cartoons are art products in which people and things are drawn in a funny way by exaggerating, humor is made on the line, and that can appeal to all age groups, including entertainment, humor, satire, thinking and visuality. It is widely used in scientific and technical issues as it enables information and messages to be delivered easily and permanently (Ozsahin, 2009; Balim et al., 2016; Al-Rabaani and Al-AAmri, 2017). Therefore, cartoons should be used scientifically in the field of education in order to ensure the permanence and easy transfer of the information required for learning.

In addition, cartoons can be designed as materials that can be used to teach the concepts to students in a correct and fun way (Kete et al., 2009). Concept cartoons are one of the visual tools that we can prepare and use on the basis of the constructivist approach in order to create permanent learning by ensuring the active participation of students in the course during the learning and teaching process in biology education. It is provided by speaking in balloons and presenting it with very little use of language (Evrekli and Balim, 2010; Yin et al., 2016; Akbas and Kilic, 2019).

In concept cartoons, the events encountered in daily life are the presentation of two or more characters' conversations on problems or ideas in the form of speech bubbles. (Inel et al., 2009). While cartoons are used to make individuals laugh, concept cartoons are used to entertain students and to question their knowledge, to direct them to think and discuss (Evrekli and Balim, 2010; Sengul and Uner, 2010).

Concept cartoons, which can be used as tools to develop the conceptual event, are seen to create an efficient teaching environment in a social process. (Kete et al., 2009; Birisci et al., 2010).

In a study realized by Inel et al., (2009), that the students' opinions were positive about the use of concept cartoons and the concept cartoons increase the understanding and the interests of the lessons, researchers found that cartoons positively affect the academic achievement of students and made a significant difference. 
In the light of the utilized literature, this study is the one that tries to show that concept cartoons, which are generally entertaining and also effective visual materials, can be used in a constructivist approach in education, especially in biology teaching, teachers can benefit from the learning-teaching environment in order to create effective, efficient and permanent learning.

The purpose of this study is to determine the effect of teaching with concept cartoons in biology teaching on student achievement and the permanence of learned knowledge based on the constructivist learning approach. Problems and subquestions were determined within the framework of this aim.

The problem of the study is, is there a significant difference between the learning levels of the experimental group taught with concept cartoons and the traditional control group in the "Ecosystem Ecology" unit of the secondary school biology course (10th grade)?

1. What is the effect of teaching with concept cartoons on student achievement?

2. What is the effect of concept cartoons on the permanence of knowledge?

\section{Materials and methods}

In the study, the control group pre-test, post-test quasiexperimental research method was used. The quasiexperimental method is the most commonly used method in educational research when it is not possible to keep all variables under control (Gul and Yesilyurt, 2011).

\subsection{Study group}

The 10th grade students studying at Kazım Karabekir Technical and Industrial Vocational High School in Yunus Emre district of Erzurum province were selected as the study group. The universe of the study covers the 10th grade digital classes with biology lessons. The study was applied on 49 students in two of the 10th digital classes. Two classes were determined with the permission of the school principal and biology teachers. In the study, achievement test was applied to two classes in the school selected with the appropriate sampling method before starting the actual application and it was determined that there was no significant difference between the groups. Accordingly, a class was selected by random method as a sample from these two classes, which were found to be equivalent, and the experimental group was formed by showing the cartoons in the form of slides in a computerized environment and applying lectures with cartoons. In the other class, the control group was formed by applying the method of direct instruction without showing the cartoons.

\subsection{Data collection tool}

In the study, biology achievement tests including threestage pre-test, post-test and permanence test consisting of 25 questions on the subject of "Ecosystem Ecology (especially Ecosystem Structure)", which is the third unit of the 10th grade biology course, from the preparation course books of the student Selection Examination (ÖSS), were prepared and used. The correct answer for each item was determined as 4 points and the maximum score to be obtained from the test was 100 . The tests prepared were examined by course teachers, science educators and measurement experts.

\subsection{Research application}

This study includes a seven-week application. The study was applied to a total of 49 numerical class students, including 30 experimental groups and 19 control groups. In both groups, the lesson was taught by the same biology teacher and practices related to the lesson were made.

Pre-test, post-test and permanence test were applied to both experimental and control groups. A pre-test was applied to both groups before the lesson was taught. Then, the control group was taught with the traditional teaching method, which is direct instruction.

In the experimental group, the researched concept cartoons were given to the group as a material with the method of teaching, and the lesson was presented as slides supported with cartoons, and was actively processed in the form of questions and answers based on the constructivist approach. It was administered to both groups during normal class hours. In the experimental group, in which the method of lecturing with cartoons was applied, it was observed that the lesson was fun and enjoyable, every student attended to the lesson, students read and understand cartoons and laughed during the lesson, and the lesson was handled in a pleasant way.

After the topic of the lesson was finished, a post-test was applied to both groups. After four weeks, a statistical analysis and evaluation of the data was performed by applying a retention test to both groups.

\subsection{Analysis of the data}

The analysis of the data was done through the SPSS 15 package program. One-way analysis of variance was used to determine the effects of independent variables on the dependent variable (Biology Field Knowledge Test Result). A significance level of 0.05 was adopted in the comments regarding whether the differences between groups are significant or not.

\section{Results}

Random pre-test and post-test achievement tests were applied to the control group and the experimental group in the analysis of the findings on the achievements of the students in the biology lesson Ecosystem Ecology with the concept cartoons. In addition, the retention test was applied to the groups after 4 weeks. The data were analyzed by comparison method.

In the study, pre-test averages, standard deviations of the experimental and control groups for the success test are given in Table 1, post-test averages and standard deviations are given in Table 2. The retention test averages and standard deviations applied to the groups four weeks after the pre-test and post-test applications are given in Table 3 . In addition, the pre-test, posttest and retention test analysis results regarding the achievement test of the students in the experimental and control groups are compared in Table 4.

\section{Table 1}

Descriptive statistics table of the experimental and control groups for the pretest.

\begin{tabular}{|c|c|c|c|}
\hline Groups & $\mathbf{N}$ & $\bar{X}$ & SS \\
\hline Experiment & 30 & 23.26 & 9.91 \\
\hline Control & 19 & 20.21 & 9.84 \\
\hline $\mathbf{t}$ & & & Importance Level (p) \\
\hline 1.054 & & & 0.297 \\
\hline
\end{tabular}


An independent sample t test was conducted to determine whether there was a significant difference between the experimental and control groups in terms of pre-test scores. According to the analysis results, it was revealed that there was no significant difference ( $p>0.05)$ between the groups.

Table 2

Descriptive statistics table of the experimental and control groups belonging to the posttest.

\begin{tabular}{|c|c|c|c|}
\hline Groups & $\mathbf{N}$ & $\bar{X}$ & SS \\
\hline Experiment & 30 & 60.66 & 11.02 \\
\hline Control & 19 & 34.31 & 12.45 \\
\hline $\mathbf{t}$ & & & Importance Level (p) \\
\hline 7.752 & & & 0.000 \\
\hline
\end{tabular}

An independent sample $t$ test was conducted to determine whether there was a significant difference between the experimental and control groups in terms of posttest scores. According to the analysis results, it was revealed that there was a significant difference $(p<0.05)$ between the groups.

Table 3

Descriptive statistics table of the retention test of the experimental and control groups.

\begin{tabular}{|c|c|c|c|}
\hline Groups & $\overline{\mathbf{N}}$ & $\overline{\bar{X}}$ & SS \\
\hline Experiment & 30 & 47.06 & 13.06 \\
\hline Control & 19 & 32.63 & 9.91 \\
\hline $\mathbf{t}$ & & & Importance Level (p) \\
\hline 4.118 & & & 0.000 \\
\hline
\end{tabular}

In order to determine whether there was a significant difference between the experimental and control groups in terms of retention test scores, an independent sample $t$ test was conducted. According to the analysis results, it was revealed that there was a significant difference $(p<0.05)$ between the groups.

\section{Table 4}

Comparison table of pretest, posttest and permanence test analysis results for the achievement test of students in the experimental and control groups.

\begin{tabular}{lccc}
\hline Groups & $\begin{array}{c}\text { Pretest } \\
\text { Average }\end{array}$ & $\begin{array}{c}\text { Posttest } \\
\text { Average }\end{array}$ & $\begin{array}{c}\text { Permanence- } \\
\text { test Average }\end{array}$ \\
\hline \multirow{2}{*}{ Experiment } & 23.26 & 60.66 & 47.06 \\
& (DGÖTO) & (EGPOTA) & (DGKTO) \\
\multirow{2}{*}{ Control } & 20.21 & 34.31 & 32.63 \\
& (KGÖTO) & (KGSTO) & (KGKTO) \\
\hline
\end{tabular}

Before the application, it was investigated whether there is a significant difference between the groups in terms of student achievement. As seen in Table 4, the results obtained from the analyzes performed before the actual application revealed that there was no statistically significant difference between the experimental and control groups in terms of biology knowledge success at the beginning. Table 4 shows that the success of the experimental group increased after the teaching method with concept cartoons was applied and the information was more permanent.

Additionally, the pre-test average (EGPrTA) of the experimental group was calculated as 23.2667, while the pre-test average (CGPrTA) of the control group was calculated as 20.2105. These results show that the knowledge levels of the groups before the application were very close to each other and that there was no significant difference between the groups.
After the application, the posttest average (EGPoTA) of the experimental group was 60.6667 , while the posttest average (CGPoTA) of the control group was 34.3158. As a result of the analysis, an average significant difference was found between the experimental and control groups (CGPoTA $<$ EGPoTA). This result shows that the teaching practices carried out with concept cartoons are more effective in teaching the "Ecosystem Ecology" unit of the biology lesson than traditional teaching.

In addition, according to the results of the permanence test applied and shown in Table 4, despite the four weeks after the application, the control group permanence test average (CGPTA) was calculated as 32.6316 , while the experimental group permanence test average (EGPTA) was calculated as 47.0667 (CGPTA $<$ EGPTA). As a result of this retention test analysis, it was determined that concept cartoons are a suitable material for teaching and provide permanent traced learning. This result shows that teaching with concept cartoons has a positive effect on students' learning biology knowledge compared to the traditional method.

\section{Discussion}

Raising individuals who produce knowledge and use the information they produce will be possible primarily by learning to learn. Learning to learn requires understanding of learning strategies (Tasdemir and Tay, 2007).

Learning takes place through the mental participation of the individual himself. Learning does not occur by simply storing information in the student's brain through the narrative method (Anderson and Mack, 2019; Ball, 2020). For this reason, a contemporary teacher knows the importance of using new methods and techniques in order to gain new behaviors to his students and tries to show his students to practice by learning new learning strategies. Compared to the traditional teacher, the modern teacher provides a learning environment that appeals to more sensory organs, meeting the different learning needs of the students and providing a multiple learning environment (Calalb, 2017; Yagci and Guneyli, 2018). It brings students closer to the lesson, arouses their interest, simplifies the subject and makes it easier to understand. A teacher using only one method and technique cannot be successful. As much as possible, teachers should use materials and tools that attract attention, ensure active participation of the student in the lesson, and appeal to the student's many senses, such as slide pictures, concept maps and concept cartoons. Permanent learning will be achieved in the learning and teaching process with these visual materials (Wijaya and Bunau, 2017; Erdem and Koc, 2019; Sáez-López et al., 2019; Woldeamanuel et al., 2020).

The problem of the study is determined as "Is there a significant difference between the learning levels of the experimental group that is taught with concept cartoons in the Ecosystem Ecology unit and the control group that has traditional education?". In line with the solution of the problem in question, "What is the effect of teaching with concept cartoons on student achievement? What is the effect of teaching with concept cartoons on the retention of the learned information?" Answers to these sub-questions were sought.

As a result of the analysis; It was observed that there was no significant difference between the pretest achievement test scores of the experimental and control groups and the groups were considered to be relatively equal. After the application, the achievement test was applied to the experimental and control groups as a post test and it was determined that there was a 
significant difference between the posttest success scores of the groups. In line with this finding, it can be said that teaching with concept cartoons in the learning and teaching environment causes a significant difference in students "achievement and that concept cartoons affect students" success positively.

In order to examine the effect of teaching with concept cartoons on the retention of the learned information, a retention test was applied to the experimental and control groups 4 weeks after the application. As a result of the retention achievement test analysis, it can be said that there is a significant difference between the experimental group and the control group, and teaching with concept cartoons provides the permanence of the learned information and positively contributes to permanent learning.

In the study by Kete et al. (2009), "Attitudes of pre-service teachers about the use of cartoons in their worksheets", it has been revealed that the analysis findings of the attitudes of teacher candidates that cartoons have an effect on learning, create permanent knowledge, create an environment for curiosity, thinking, research and discussion, provide motivation, and are entertaining and instructive. It is seen that the teacher candidates showed a high attitude to the item "I quickly perceive the message given by cartoons" by $87 \%$, to the item cartoons are a good educational tool, $73 \%$, to the item cartoons reinforce the meaning of the topic, $84 \%$ to the item that cartoons are entertaining and instructive, and $100 \%$ to the item I never forget the subject about cartoons. In the study of Inel et al. (2009) on the use of concept cartoons in science teaching, students stated that they wanted concept cartoons to be used in science lessons, that concept cartoons are beneficial in many ways, help them understand the lesson and increase their interest in the lesson, such as how the lesson is handled differently and the concept cartoons are illustrated. They stated that they liked concept cartoons due to their characteristics. The views of the students in the findings of this study and the teachers' views in the study of Kete et al. (2009) support each other and are in line with the findings of our study.

Ozsahin's (2009) "Teaching Geography with Cartoons" supported the students' opinions that the cartoons would be used in the lesson in the survey conducted on 12th grade students. More than $75 \%$ of the students advocated the use of cartoons and other visual materials in lessons, and more than $80 \%$ of the students argued that if their teachers show cartoons related to the subject in lessons, it will make the lessons more enjoyable and they can learn the subjects more comfortably. These findings are also in parallel with the studies conducted.

Balim et al., (2008), in the study "The effect of the use of concept cartoons in science teaching on students' academic achievement and inquisitive learning skills perceptions" is that the independent variable is concept cartoons, there is no significant difference between the experimental group and the control group posttest academic achievement scores, the analysis. As a result, it was determined that concept cartoons alone do not have any effect on academic achievement. Initially, it was observed that this finding did not support our study. However, it was stated in the study that when concept cartoons are used together with different methods and techniques, they can contribute positively to academic success. In line with this view, in the practice of our study, it was determined that the concept cartoons had a positive effect on teaching with the active participation of the student, in the form of questions and answers based on the constructivist approach supported by slide display on the computer and supported by findings of Balim et al.,
(2008). The opinion was reached by analyzing the findings obtained.

In the research findings of the study named "The effect of the use of cartoons on students 'academic achievement and their views on the lesson" in which the effectiveness of the use of cartoons in Social Studies lesson was investigated, it was determined that the use of cartoons had a positive effect on students' academic achievement (Akengin and Ibrahimoglu, 2010).

In study of Evrekli and Balim (2010), it was investigated whether there was a significant difference between the post-test academic achievement scores of the students in the experimental group studying with activities based on the use of concept cartoons and the students in the control group studying only with the "Science and Technology" curriculum, and as a result of the analysis findings, experimental and control, it was determined that there is a significant difference between the posttest academic achievement scores of the groups. In line with this finding, it was stated that the activities based on the use of concept cartoons caused a significant difference in the academic achievement of students only according to the activities in the science and technology curriculum.

Erdogan and Ozsevgec (2012) developed student-centered materials for "learning the greenhouse effect and global warming" and after the application these materials, they found significant differences between the pre-test and post-test mean scores of the students. They concluded that the concept cartoons used ensured active participation by placing the student at the center and effective on eliminating students' misconceptions.

Cinici et al., (2014) were found a significant difference in favor of the experimental group between the achievement levels of the students in Science and Technology lesson in the eighth class "Cell Division and Inheritance" unit. They stated that the students liked participating in collaborative studies and discussions in the argument-generating process, and they found the use of cartoons was funny. Additionally, they observed that students had the opportunity to directly participate in the thinking, discussion and questioning-style activities and they had the opportunity to learning by applying cognitive and social activities related to the scientific process.

Kaplan et al., (2014) observed that the students had misconceptions about square root numbers in mathematic class. They concluded that the concept cartoons and traditional teaching were effective in eliminating misconceptions. They also stated that while traditional teaching only caused a positive change in comparing square-rooted numbers, concept cartoons had a positive effect on all achievements. In addition, their results showed that concept cartoons were more effective in comparing concept cartoons and traditional teaching.

In another study, it was proven that peer learning with concept cartoons enhance students' interest in positive manner. According to researchers' obtained data, 39.84\% of the respondent people were agreed to this. Also, analysis were indicated that PLCC can enhance the interests of the students (Yin et al., 2016). In a recent study realized by Al-Rabaani and Al-AAmri, (2017) showed that in lessons of social studies, using cartoons has significantly increased students' water awareness level, when compared to the other traditional methods. They added that the cartoons create a learning environment to the students and more interest for looking and reading the materials as a result of the included satire symbols irony, comics, in the used cartoons. Lately, Dayan, 2021 studied the metaphors produced by primary school 3rd grade students for concept 
cartoons, which are a teaching material in the "Life Studies" course. Students produced 77 metaphors for concept cartoons, and these metaphors were discussed under 10 categories. These categories are; description, fun, information source, life, object, educator/instructor, place, person and profession, action and others.

The researcher concluded that concept cartoons, one of the metaphors produced by the students, are justifications emphasizing that they are entertaining and informative.

As a result of the research conducted in order to create a stimulating effect for the use of cartoons in biology teaching by describing different perspectives on the use of concept cartoons as visual material in education and training in line with the researches and perspectives in the literature; The use of concept

\section{References}

Afrizon, R., Sari, S. Y., Hidayati, H., \& Anshari, R. (2019). Dissemination of statistical physics learning materials based on KKNI with the constructivist approach. Journal of Physics: Conference Series, 1317(1), 012166.

Akbas, E. E., \& Kilic, E. (2019). Evaluation of the use of concept cartoon activities in teaching the translation concept from students' perspectives. Journal of Education and Training Studies, 8(1), 1-13.

Akengin, H., \& Ibrahimoglu, Z. (2010). Sosyal bilgiler dersinde karikatür kullanımının öğrencilerin akademik başarısına ve derse ilişkin görüşlerine etkisi. Ondokuz Mayıs Üniversitesi Eğitim Fakültesi Dergisi, 29(2), 1-19.

Al-Rabaani, A. H., \& Al-AAmri, I. H. (2017). The effect of using cartoons on developing Omani grade 4 students' awareness of water issues and their attitudes towards using them in teaching social studies. Journal of Social Studies Education Research, 8(1), 35-46.

Anderson, K. M., \& Mack, R. (2019). Digital storytelling: A narrative method for positive identity development in minority youth. Social Work with Groups, 42(1), 43-55.

Balim, A. G., Inel, D., \& Evrekli, E. (2008). Fen öğretiminde kavram karikatürü kullanımının öğrencilerin akademik başarılarına ve sorgulayıcı öğrenme becerileri algılarına etkisi. Illkogretim Online, 7(1), 188-202.

Balim, A. G., Inel-Ekici, D., \& Ozcan, E. (2016). Concept cartoons supported problem based learning method in middle school science classrooms. Journal of Education and Learning, 5(2), 272-284.

Ball, J. (2020). An arts-based, peer-mediated Story Board Narrative Method in research on identity, belonging and future aspirations of forced migrant youth. Migration, Mobility \& Displacement, 5(1), 83-93.

Birisci, S., Metin, M., \& Karakas, M. (2010). Pre-service elementary teachers' views on concept cartoons: a sample from Turkey. MiddleEast Journal of Scientific Research, 5(2), 91-97.

Buckley, J. B., \& Michel, J. O. (2020). An examination of higher education institutional level learning outcomes. Innovative Higher Education, 117.

Cakmak, O., \& Havedanli, M. (2004). Biyoloji eğitiminde kavram haritalarının önemi ve diğer yöntemlerden farkı. XIII. Ulusal Eğitim Bilimleri Kurultayl, 6-9 Temmuz 2004, İnönü Üniversitesi, Eğitim Fakültesi, Malatya.

Calalb, M. (2017). The synergy between digital tools and modern constructivist pedagogies. Fostering Knowledge Triange in Moldova: 2017 Conference Proceedings, Academy of Economic Studies of Moldova, Centre for Studies in European Integration, 16-23.

Cinici, A., Ozden, M., Akgun, A., Herdem, K., Deniz, Ș. M., \& Karabiber, H. L. (2014). Kavram karikatürleriyle desteklenmiş argümantasyon temelli uygulamalarin etkinliğinin incelenmesi. Adlyaman Üniversitesi Sosyal Bilimler Enstitüsü Dergisi, (18), 571-596.

da Costa, F. R., \& Pelissari, A. S. (2016). Factors affecting corporate image from the perspective of distance learning students in public higher education institutions. Tertiary Education and Management, 22(4), 287-299.

Dayan, G. (2021). İlkokul 3. sınıf öğrencilerinin kavram karikatürlerine ilişskin metaforik algıları. Uluslararası Eğitim Araştırmacıları Dergisi, $3(2), 330-345$

Demiralp, N. (2007). Coğrafya eğitiminde materyaller ve 2005 coğrafya cartoons in biology teaching in a computer-aided environment in the form of slideshows contributes positively to student success, increases students' interest in the lesson, makes the lesson environment entertaining and instructive, enables the student to participate actively in the lesson, encourages students to learn more quickly and more permanently. And it can be said that it effects students positively towards biology subjects.

Conflict of interest: The authors declare that they have no conflict of interests.

Informed consent: This manuscript did not involve human or animal participants; therefore informed consent was not collected.

dersi öğretim programı. Kastamonu Ĕ̈itim Dergisi, 15(1), 373-384.

Erdem, A., \& Koc, E. S. (2019). Active learning methods and techniques preferred by teacher candidates. Journal of Education and Future, (16), 29-38.

Erdogan, A., \& Ozsevgec, L. C. (2012). Kavram karikatürlerinin öğrencilerin kavram yanılgılarının giderilmesi üzerindeki etkisi: Sera etkisi ve küresel 1sınma örneği. Turkish Journal of Education, 1(2), 38-50.

Evrekli, E., \& Balim, A. G. (2010). Fen ve teknoloji öğretiminde zihin haritası ve kavram karikatürü kullanımının öğrencilerin akademik başarılarına ve sorgulayıcı öğrenme becerileri algılarına etkisi. Batı Anadolu Ë̆itim Bilimleri Dergisi, 1(2), 76-98.

Fryer, L. K., Ainley, M., Thompson, A., Gibson, A., \& Sherlock, Z. (2017). Stimulating and sustaining interest in a language course: An experimental comparison of chatbot and human task partners. Computers in Human Behavior, 75, 461-468.

Gul, S., \& Yesilyurt, S. (2011). Yapılandırmacı öğrenme yaklaşımına dayalı bilgisayar destekli öğretimin öğrencilerin tutumları ve başarıları üzerine etkisi. Necatibey Eğitim Fakültesi Elektronik Fen ve Matematik Ĕ̈itimi Dergisi, 5(1), 94-115.

Gunawardhana, L. P. D., \& Palaniappan, S. (2016). Possibility of using multimedia application for learning. GSTF Journal on Computing (JoC), 5(1), 77.

Hourani, L., Lambert, S., Peeler, R., Lane, B., \& Borst, C. (2017). Graphic novels: A new stress mitigation tool for military training: Developing content for hard-to-reach audiences. Health Communication, 32(5), 541-549.

Inel, D., Balim, A. G., \& Evrekli, E. (2009). Fen öğretiminde kavram karikatürü kullanimina ilişin öğrenci görüşleri. Necatibey Faculty of Education Electronic Journal of Science \& Mathematics Education, 3(1), 1-16.

Kaplan, A., Altayli, D., \& Ozturk, M. (2014). Kareköklü sayılarda karşılaşılan kavram yanılgılarının kavram karikatürü kullanılarak giderilmesi. Uludağ Universitesi Ĕ̈itim Fakültesi Dergisi, 27(1), 85102.

Kete, R., Avcu, T., \& Aydin, A. (2009). Öğretmen adaylarının çalışma yapraklarında karikatür kullanımına ait tutumları. Kastamonu Eğitim Dergisi, 17(2), 531-540.

Klein, C., Lester, J., Rangwala, H., \& Johri, A. (2019). Learning analytics tools in higher education: Adoption at the intersection of institutional commitment and individual action. The Review of Higher Education, 42(2), 565-593.

Kwahk, K. Y., \& Park, D. H. (2018). Leveraging your knowledge to my performance: The impact of transactive memory capability on job performance in a social media environment. Computers in Human Behavior, 80, 314-330.

Langley, J., Wolstenholme, D., \& Cooke, J. (2018). 'Collective making' as knowledge mobilisation: the contribution of participatory design in the co-creation of knowledge in healthcare. BMC Health Services Research, 18(1), 585-594.

Liang, D., Yuexin, Q., \& Shuo, Z. (2019). Research on multimedia teaching of physical education class based on online physical education curriculum construction. 2019 5th International Workshop on Education, Development and Social Sciences, 1-5.

Marques, S. C., Ferreira, F. A., Meidutè-Kavaliauskienė, I., \& Banaitis, A. 
(2018). Classifying urban residential areas based on their exposure to crime: A constructivist approach. Sustainable Cities and Society, 39, 418-429.

Naude, M., \& Meier, C. (2019). Elements of the physical learning environment that impact on the teaching and learning in South African Grade 1 classrooms. South African Journal of Education, 39(1), 1-11.

Neeley, T. B., \& Leonardi, P. M. (2018). Enacting knowledge strategy through social media: $\mathrm{P}$ assable trust and the paradox of nonwork interactions. Strategic Management Journal, 39(3), 922-946.

Opare, S. A., Manu, F. O., Ackah, J. K., \& Akrosumah, S. M. (2018). An investigation into teaching and learning materials (TLMs) science tutors use to assess physics lessons in the colleges of education in Ghana. American Journal of Modern Physics and Application, 5(4), 91 96.

Ozalp, I. (2006). Karikatür tekniğinin fen ve çevre eğitiminde kullanılabilirliği üzerine bir araştırma, Yüksek Lisans Tezi, (pp. 1-144) Celal Bayar Üniversitesi, Fen Bilimleri Enstitüsü, Türkiye.

Ozsahin, E. (2009). Karikatürlerle coğrafya öğretimi. Marmara Coğrafya Dergisi, (20), 101-122.

Ozyigit, I. I. (2020). About life sciences and related technologies. Frontiers in Life Sciences and Related Technologies, 1(1), 1-11.

Sáez-López, J. M., Sevillano-García, M. L., \& Vazquez-Cano, E. (2019). The effect of programming on primary school students' mathematical and scientific understanding: educational use of mBot. Educational Technology Research and Development, 67(6), 1405-1425.

Sengul, S., \& Uner, I. (2010). What is the impact of the teaching "Algebraic Expressions and Equations" topic with concept cartoons on the students' logical thinking abilities?. Procedia-Social and Behavioral Sciences, 2(2), 5441-5445.

Silva, L. D. M., \& Francis, J. W. (2020). "It is like a little journey": Deaf international futsal players' and coaches' experiences in collaborative blended learning. International Sport Coaching Journal, 1(aop), 1-14.

Tasdemir, A., \& Tay, B. (2007). Fen bilgisi öğretiminde ögrencilerin öğrenme stratejilerini kullanmalarının akademik başarıya etkileri. Uludă̆ Üniversitesi Ĕgitim Fakültesi Dergisi, 20(1), 173-187.

Tyler-Wood, T., Johnson, K., \& Cockerham, D. (2018). Factors Influencing Student STEM Career Choices: Gender Differences. Journal of Research in STEM Education, 4(2), 179-192.

Uslu, B., \& Celikoz, M. (2020). The study of preschool teachers' and principals' opinions on Turkish Education System. International Journal of Modern Education Studies, 4(1), 1-23.

Wiewiora, A., Chang, A., \& Smidt, M. (2020). Individual, project and organizational learning flows within a global project-based organization: exploring what, how and who. International Journal of Project Management, 38(4), 201-214.

Wijaya, B., \& Bunau, E. (2017). Improving students' reading comprehension through pre-reading strategies at tenth grade students. Jurnal Pendidikan dan Pembelajaran Khatulistiwa, 6(4), 113.

Woldeamanuel, Y. W., Abate, N. T., \& Berhane, D. E. (2020). Effectiveness of concept mapping based teaching methods on grade eight students' conceptual understanding of photosynthesis at Ewket Fana primary school, Bahir Dar, Ethiopia. EURASIA Journal of Mathematics, Science and Technology Education, 16(12), em1918.

Yagci, E., \& Guneyli, A. (2018). An analysis of the professional competencies of Turkish language and literature teachers on the basis of the ability of using and managing technology. EURASIA Journal of Mathematics, Science and Technology Education, 14(7), 3389-3404.

Yesilyurt, S. (2005). Biyoloji Eğitimi öğrencilerinin biyoloji laboratuar uygulamalarında karşılaştıkları güçlüklerin belirlenmesi üzerine bir araştırma. Çukurova Üniversitesi Eğitim Fakültesi Dergisi, 2(30), 8896.

Yin, K. Y., Bing, K. W., \& Zakariya, Z. (2016). Peer learning with concept cartoons mediated computer in secondary school economics. International Journal of Business and Social Science, 7(12), 93103.

Cite as: Aslan, A., Aslan Engin, T., Kurmanbekova, G., Kayalar, F., Kayalar, F., Karagoz, Y., \& Engin, A. (2020). The effect of biology teaching with concept cartoons based on constructivist learning approach on student achievement and permanence of knowledge. Front Life Sci RT, 2(1), 14-20. 